\title{
Rationality of Teacher for Principal Career Opportunities Negation
}

\author{
Irianto $^{1^{*}}$, Ibrahim ${ }^{2}$, Wahyudi $^{3}$, Salviana $^{3}$ \\ ${ }^{I}$ Doctor Candidate of Sociology of the University of Muhammadiyah Malang \\ ${ }^{2}$ Professor of Sociology of the University of Muhammadiyah Malang, Muhammadiyah Malang \\ ${ }^{3}$ Doctors of Social Welfare of the University of Muhammadiyah Malang \\ *Corresponding Author: Irianto, Doctor Candidate of Sociology of the University of Muhammadiyah \\ Malang
}

\begin{abstract}
The main purpose of this study is describing the rationality of teachers on the negation of the career opportunities of principals in Malang Area. Then, researcher wants to describe the motives (in order to motive and due to motive) of teachers who are competent in negating the career opportunities of principals in Malang, East Java, Indonesia.

This research used Weber's social definition paradigm(Ritzer, 2004) qualitative approach, type of phenomenological research, data collection using in-depth interview techniques (Creswell, 2018)Data analysis using IPA (Interpretative Phenomenological Analysis) with six stages including: 1. Reading an reReading; 2. Initial Nothing; 3. Developing Emergent Themes; 4. Searching for Connections a Cross Emergent Themes; 5. Moving the Next Cases; and 6. Looking for Connections a Cross Emergent Themes (Smith, 2009).
\end{abstract}

The results of data analysis are discussed with Rational Choice Theory Coleman (Ritzer \& Goodman, 2007) and Phenomenology Theory (Schutz, 1973).

Research results conclusions Teachers as Actors (individuals) have considered resources and norms before making decisions and actions in line with Coleman's rational choice theory. Found Motive cause and purpose Motive behind the rational action taken by the teacher as an actor in line with Schuzt's Phenemenology theory.

Key words: Teacher Rationality, Career Negation, Principal.

\section{INTRODUCTION}

The school principal is considered the factor that determines whether the institution he leads will achieve success or unsuccessful. Principals whose have the foresight and accuracy in identifying, formulating, packaging and describing policies, strategies and operational education programs. Will give an answer whether the school provides quality education services or vice versa.

The importance of the principal's role is in line with the results of the study (Walid, 2018); (Isjuandi \& Sutisna, 2017); (Baihaqi et al., 2012); (Nugroho, 2017); (Maryono, 2015); (Irianto, 2014).

Based on the explanation above, it is important to consider when there are policies related to school principal recruitment, the processes and procedures related to school principal recruitment must be carried out in accordance with the objectives in the education sector.

Research findings (Farr, 2004), (Baihaqi et al., 2012)and research (Fatah, 2015)there is an interesting phenomenon which is the phenomenon of teachers' lack of interest in recruiting prospective principals. This phenomenon is of interest to researchers, to find out how in the midst of a materialistic life, where position significantly influences income but does not attract teachers to capture career opportunities as school principals.

Based on empirical and theoretical studies on the recruitment of principals, many have been carried out such as (Farr, 2004), (Baihaqi et al., 2012) and (Nugroho, 2017). Including research on the 
meaning of the principal's position (Saifudin, 2015). However, no research has been found that reveals the process of forming teacher rationality attitudes and motives for negating the career opportunities of the principal.

Based on the theoretical empirical study above, it turns out there is a gap or emptiness of the study area that has not been touched, there will be a first problem statement, what is the rationality of the teacher over the negation of the principal's career opportunity choices and how the teacher's motives for negating the principal's career opportunity.

These two issues are interesting in addition to also important to be investigated because they will make new theoretical contributions in the discipline of sociology, especially educational sociology.

Teacher rationality over negation of principals 'career opportunities will be explained with theoretical thought pathway; Rational Choice James Coleman while to uncover the motives of teacher rationality over negation of principals' career opportunities will be explained with a phenomenological phenomenology Alfred Schutz.

\section{Theoretical Perspectives}

\subsection{Teori Pilihan Rasional}

Teori Pilihan Rasional is a theory of contemporary sociology. This theory is the effort of one of the figures, namely James Samuel Coleman (Ritzer \& Goodman, 2007). Coleman made a journal" Rationality and Society" intended to socialize rational choice theory thinking, Coleman's book titled "Foundation of Social Theory" based on rational choice perspective (Coleman, 2019).

Rational choice theory gives authority to the actors, in the process decision making considers the resources owned, norms, collective behavior and corporate actors before taking action.

Actors, are people acting intentionally towards a goal, with that goal formed by values or choices. Actors will take actions in order to maximize the benefits, benefits and satisfaction of their needs;

Resources, is the potential possessed by an actor that will influence the choice of actors, the greater the resources possessed, the more or more choices will be beneficial in achieving the objectives of meeting the needs of the actor.

Norms, are instruments that control the behavior of actors in society. Norms are created and maintained by a group of actors who see the benefits resulting from compliance with the norms and the losses resulting from violations committed against these norms. Coleman explained the formation of norms because of the transfer of rights and control of some people, and the acceptance of those rights and controls by some others so that the control held by each person was channeled broadly to all actors in the group holding the control - norms.

Rational choice theory has postulates or a set of assumptions that serve as guides in social studies, namely:

a. A social phenomenon is the impact of decisions, actions, attitudes, and so forth made by individuals (actors) ;

b. In principle, the actions of the actor can be understood by himself and others;

c. Every action taken by the actor through consideration / reasons that are in the minds of individuals / reserves of knowledge (postulate of rationality);

d. Reasons derived from the consideration of the actor being aware of the consequences / consequences that would arise from his actions (postulate consequentialism or instrumentalism);

e. The actor pays particular attention to the consequences his own actions have on himself;

f. Actors are able to distinguish between the disadvantages of alternative action paths and choose the path of action that has the best or positive balance (maximization or optimization).

\subsection{Theory of Phenomenology}

Phenomenology seeks to understand how humans construct important meanings and concepts within the framework of intersubjectivity (our understanding of the world is shaped by our relationships with others). Phenomenology assumes that people actively interpret their experiences and try to understand 
the world with their personal experiences. In this study, researchers want to also know the motives behind the actions of actors, the researchers present the theory of phenomenology (Schutz). The phenomenology theory of the researcher limits only the aspects of the goal motive (in order to motive) and the motive cause / reason (because motive).

As a foothold the assumptions / postulates of the phenemonological theory are:

a. Evidence of Logical Consistency (The postulate of logical consistency)

This means logical consistency requires researchers to know the validity of their research objectives so that they can be analyzed how they relate to the reality of everyday life. Can it be accounted for or not.

\section{b. The Theorem of Subjective Interpretation (The postulate of subjective interpretation)}

Researchers make effort to understand all kinds of human actions or human thought in the form of concrete actions. That is, researchers must position themselves subjectively in research in order to truly understand the human being studied in social phenomenology.

\section{c. Evidence Sufficiency(Thepostulateofadequacy)}

This proposition mandates researchers to establish a scientific construction (research) so that researchers can understand the social actions of individuals. Compliance with this proposition will ensure that the social construction formed is consistent with the existing construction in social reality.

\section{Method}

Based on the consideration of objects, problems, approaches and theories it is deemed appropriate to make the paradigm of the social definition of Max Weber's work, the paradigm of social definition does not explicitly separate social structure from social institutions. Social structures and social institutions support human actions that are full of meaning and meaning. In this paradigm, according to Weber this sociology study is directed to interpret and understand (interpretative understanding) or verstehen according to Weber's terms both in social actions and social relations. (Ritzer, 2004).

The research approach uses a qualitative approach, with the type of research being phenomenology. The main aim of the study of phenomenology is to reduce individual experiences of concepts or phenomena into an essential description or universal essence. For this purpose phenomenological researchers collect data from individuals who experience the phenomenon. (Creswell, 2018).

The location in this study is a state high school in the Malang Area of East Java, Indonesia. Subjects in the research of researchers differentiate into two types of informants, namely key informants and supporting informants. Supporting informants for this study were 6 (six) with a purposive sampling technique.

Key informants in this study are teachers who have teachers who have professional competence, pedagogical competencies, personal competencies and social competencies, but are not interested in recruiting high school (SMA) prospective principals in Malang as many as 4 (four) people.

Research data to obtain primary data in this study used in-depth interview techniques (indepth interview). To obtain data in this study, researchers in this study as a key instrument (key instrument).

Broadly speaking the interview as a data collection tool according to (Daulay, 2010) is carried out as follows:

1. Conduct in-depth interviews, spend more time listening (Epoche, Brecketing) interview process is recorded with audio recording aids and make notes- interview notes,

2. When playing back the recorded interview, there is data / information that needs to be added by researchers contacting the informant by telephone, as well as whatshapp after an agreement with the previous informant.

Data analysis and data presentation in this study used techniques interpretative phenomenology analysis (IPA)that Smith revealed in the article (Hajaroh, 2010) the implementation was divided into six stages in the order of 1) Reading and re-reading; 2) Initial noting; 3) Developing Emergent themes; 4) Searching for connections across alternative themes; 5) Moving the next cases; and 6) Looking for patterns across cases. 


\section{FINDING AND DISCUSSION}

\subsection{Discussion of Research Results with Prior Research}

The results of the study and the findings of the first previous research to conduct a study related to the selection system for school principals(Maryono, 2015), (Baihaqi et al., 2012), (Sumarno, 2015), (Farr, 2004). The two studies with evaluation studies related to school principal recruitment (Rahmadi, 2019), (Wasitohadi, 2014), (Isjuandi \& Sutisna, 2017), and (Irianto, 2014). Then third, a research with the case study about teachers' interent to become a school principal (Fatah, 2015). Four, research with a prototype study on the school principal recruitment model (Nugroho, 2017)and the fifth research on the meaning of leadership of female principals (Saifudin, 2015).

Based on the results of the study and previous research findings there are aspects of the study that have not touched the rationality of teachers over the negation of the principal's career opportunities, so this research is relatively new and interesting.

Discussion of the results of research in this first phase is focused on answering the important issues of this research carried out by looking at the similarities and differences with previous research.

The findings of this study, regarding teacher rationality over negation of principals' career opportunities, based on the findings in the field are as follows:

a. Self-experience as a consideration before making decisions

Explanation of the four informants above, shows that before making decisions the actor has considered based on his experience. Among them: The

1) Weight of responsibility as a principal if carried out by a woman who is also responsible for her family will be difficult to divide time.

2) Success in career must: depart from pleasure, focus / totality / commitment to the profession, get support from and social environment.

3) By nature women have limitations in dealing with heterogeneous and complex problems compared to men.

4) Solidarity with peers who have an interest in additional teacher assignments.

The explanation about the meaning of the position of the principal of the four informants in the research is in line with the research (Saifudin, 2015)about the meaning of the leadership of the female headmaster. While referring to the results of the study (Farr, 2004)does not reveal why teachers do not wish to become headmasters. The results of the study (Fatah, 2015) the results of the study lack of teacher interest because it is not balanced between the workload with the allowance of the principal.

This study found several factors why teachers are not interested in becoming school principals because of their personal experiences including: the complexity of the responsibilities of principals 'positions, non-formal requirements in recruiting prospective principals, principals' financial governance practices.

b. Understanding of Religion / Belief as a consideration before making a decision not to have a career as a school principal.

Explanation of the informants in this study illustrates that religious understanding / beliefs held by the informants are taken into consideration before making a decision not to have a career as a principal. Religious understanding / beliefs see position as follows:

1) Principal's position as destiny,

2) Principal's position as mandate

3) Gratitude for favor as compared to the past

4) Family Wellness as orientation

5) Male as leader, in any and certain conditions of women's leadership tolerated The

6) Attitude and positive mindset, to friends and others. 
Based on their information, research can conclude that the consideration of the understanding of religion / belief held adopted an influence before the four informants made a decision. Previous research related to the evaluation of school principal recruitment (Rahmadi, 2019), (Wasitohadi, 2014), (Isjuandi \& Sutisna, 2017), and (Irianto, 2014)only revealed evaluations of regulations related to the recruitment of prospective principals. This research is how religious / belief factors actually influence the teacher's lack of interest in recruiting prospective principals.

c. Family considerations before making a decision not to have a career as a school principal.

The family environment made consideration of the four informants in this study before making a decision not to have a career as a principal. Among them:

1) As a career wife / husband is more prioritizing husband / wife and family over the career position as a civil servant / teacher.

2) Family peace is not measured by material (economic and social factors)

The description of the four informants above emphasizes the family environment to be taken into consideration before making a decision with the findings in this study have not been touched in previous studies.

d. Bosses as a consideration before making a decision

Principal is the direct supervisor of teachers in schools, while indirectly teachers also have superiors (structurally) including school supervisors, heads of district / city regional education offices and heads of provincial education offices. Teacher superiors either directly or indirectly contributes to the teacher's career path map functionally. The explanation is as follows: The

1) dominance of the principal's role in recruiting prospective principals

2) Most principals do not conduct prospective and systematic cadres of school

3) Principals are less open to criticism from teachers as their subordinates.

4) The headmaster's communication is oriented towards the interests of his position.

Principals who are unable to accommodate problems and hope teachers will lose sympathy, leads to teacher apathy, where teachers only care about their duties as teachers to carry out teaching tasks.

Based on their explanation (three informants) the main consideration for making a decision is the behavior or actions of the school principals. The findings of this study were also not found in previous studies.

e. Regulations related to Recruitment of School Coconut Candidates as a consideration before making a decision

The Regulation about teachers who propose to be principal. The assignment of teachers as headmasters serves to lead and manage schools in an effort to improve the quality of education. The informants in this study did not make regulation a consideration because they did not have an interest in the principal's career. Regarding the recruitment of prospective principals, informants gave criticisms including:

1) Non-formal requirements (principal recommendations and cost $X$ factors) in recruiting prospective principals hinder the transparency of the recruitment process.

2) There is no evaluation of factors that cause prospective principals have never been appointed as school principals.

3) There are no sanctions for violating the implementation of prospective principals' recruitment regulations.

4) Government regulations on teachers where the principal is no longer required to teach will first impact teachers who are committed to the profession as teachers not interested in the career position of the principal; the two principals are increasingly lacking in class supervision.

5) LPPKS, openly conducts training of prospective principals to all teachers who are interested and meet the requirements "not limited to teachers who are in the process of recruiting prospective principals". 
6) School principal performance appraisal has not been able to measure achievement in the principal's leadership.

7) The ineffectiveness of the school committee's control function on financial governance is sourced from community participation for education funding.

Based on the explanation of the three informants in this study, although it does not make consideration in making decisions not as a school principal but provides criticism in the hope that a competent school principal will emerge so that can realize schools with good governance and improve the quality of education. The results of this assessment are in line with previous research related to the selection system for school principals (Maryono, 2015), (Baihaqi et al., 2012), (Sumarno, 2015).

\section{DISCUSSION OF RESEARCH RESULTS WITH THEORY}

Discussion of the results of this study is carried out by using theory as a tool of analysis in the framework of explaining theory or analysis of theory, which is in line with a theory and criticism of a theory and reinforces a theory used in this research.

Discussion of the results of research with theories focused on rational choice theory (Rational Choice Theory) and phenomenological theory (Phenomenology Theory).

\section{a. Discussion of Research Results with Rational Choice Theory}

Focus of the study in this study, researchers wanted to answer the first question in the study "What is the rationality of teachers on the negation of the career opportunities of principals in Malang Area?". The results of the sixth stage are Interpretative Phenomenological Analysis(IPA)(Smith, 2009). the patterns that emerge from the four informants of this study are then discussed with the rational choice theory (Coleman). The explanation is as follows:

Actor, in this study, is a teacher who does not take advantage of (negation) career opportunities as a principal. Whereas the action taken by the teacher is not a career as a school principal. The actions taken by the teachers in this study were not spontaneous in borrowing Weber's thoughts (Ritzer, 2004). The process before taking action The teachers in this study began with a variety of considerations if referring to rational choice theory, the first consideration is self-potential and the second consideration is the norms.

Teachers as actors have potential in themselves which Coleman called Resources, in this study the resources owned by teachers include:

1) Self-Experience, self-experience consists of:

a) Weight of responsibility as a school principal if carried out by a woman who is also responsible for her family difficult to divide time.

b) Success in career must: depart from pleasure, focus / totality / commitment to the profession, get support from and social environment.

c) By nature women have limitations in dealing with heterogeneous and complex problems compared to men.

d) Solidarity with peers who have an interest in additional teacher assignments.

2) Religion / Beliefs embraced, consisting of:

a) Position of the principal as destiny;

b) Position of the principal as a mandate to achieve the blessing of Allah SWT .;

c) Gratitude for the pleasure of being a Government Teachers (PNS) with profession benefit;

d) Wellness of family tranquility as orientation;

e) Men as leaders, in certain situations and conditions women's leadership can be tolerated;

f) Positive minded, to friends and others.

3) The Family Environment, consisting of:

a) As a career wife / husband, prioritizes husband / wife and family over career positions as civil servants / teachers;

b) Family peace is not measured in material terms (economic and social factors). 
The teacher is socially bound by the rules that Coleman called Norma, norm which controls the teacher as an actor in an educational institution (school) consisting of three, namely:

4) Teacher's Supervisor and Behavior The

a) dominant role of the principal in the recruitment of prospective principals;

b) Most school principals do not nominate prospective principals in a structured and systematic way

c) Some school principals are less open to criticism from teachers as their subordinates.

d) The headmaster's communication is oriented towards the interests of his position.

e) Principals who are not able to accommodate problems and hope teachers will lose sympathy usually teachers only care about their duties as teachers carry out teaching tasks.

5) Principal recruitment regulations for prospective principals

a) Non-formal requirements (principal recommendations and factor $X$ costs) in recruiting prospective principals hinder the transparency of the recruitment process.

b) There is no evaluation of factors that cause prospective principals have never been appointed as school principals.

c) There are no sanctions for violations of the implementation of prospective principals recruitment regulations

d) Regulations related to teacher assignments, where principals are no longer obliged to teach will first impact teachers who are committed to the profession as teachers not interested in the principal's career position; the two principals are increasingly lacking in class supervision.

e) The Principal Empowerment Development Institute (LPPKS), openly conducts training of prospective principals to all interested teachers and meets the requirements "not limited to teachers who are in the process of recruiting prospective principals".

f) School principal performance appraisal has not been able to measure achievement in the principal's leadership.

g) The ineffective function of the school committee's control over financial governance originates from community participation in funding education.

6) Cultural ethics values

a) Principal's social relations give priority to external interests (vertical and horizontal).

b) The teacher's pragmatism because the headmaster has not become an example that can be used as an example of the attitude of his behavior.

c) The attitude of teacher apathy towards the principal's leadership pattern does not accommodate problems at school.

Referring to the problematic focus of how teacher rationality is over negation of principals' career opportunities in Malang Area, the findings of this study are in line with rational choice theory thinking (Colemen) which requires two main elements namely actors and resources. The teacher as an actor, before taking action the process begins with a variety of considerations (resources) possessed including self-experience, religious understanding / beliefs adopted and the family environment. The teacher as an actor acts taken in order to maximize the benefits, benefits and satisfaction of their needs.

Based on the above research findings, the description is as shown in Figure 1 below: 


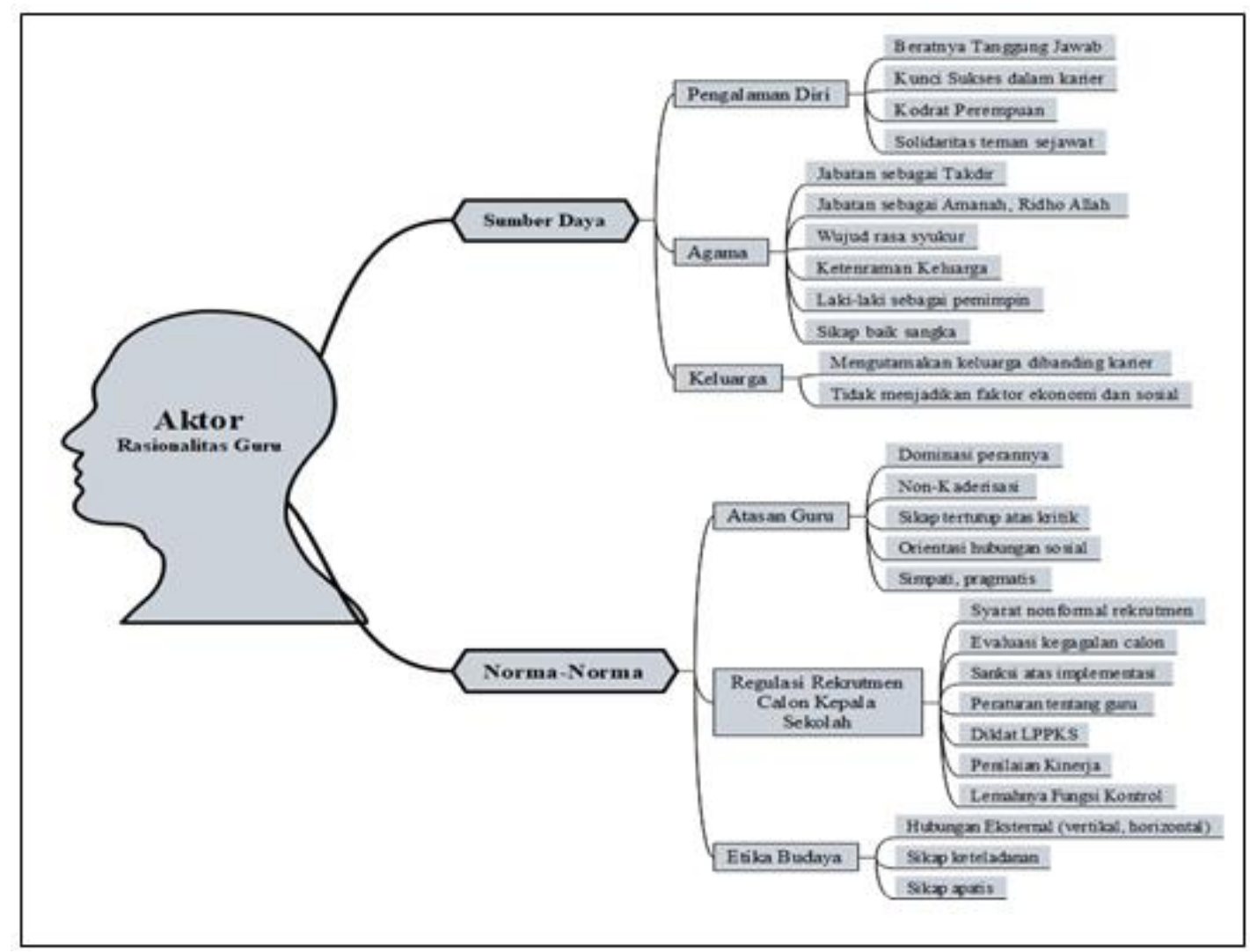

Figure1. Discussion of Research Results with Rational Choice Theory (Colemen)

Source: Research

\section{b. Dicussion Result of Research Results with Phenomenology Theory}

In this study, researchers want to also know the motives behind the actions of actors, then researchers present the theory of phenomenology (Schutz). The phenomenology theory of the researcher limits only the aspects of the goal motive (in order to motive) and the motive cause / reason (because motive).

Motive is the context of meaning which is the subjective feeling of the actor or individual as the basis for his behavior. The following will explain the motives for the reasons teachers as actors for negating the career opportunities of principals in Malang Area: The

1) Experience of having been a private school principal and being a vice-principal, had no interest in the position of principal.

2) Permendikbud's implementation of recruitment of prospective principals is not as expected.

3) The principal's position is seen from the perspective of the religion / belief held.

4) Roadmap for teacher career guidance that is not structured and systematized.

While the motives for the reasons for the teacher as an actor for the negation of the career opportunities of the principal in Malang Area are as follows:

1) Schools that major in teacher training aim to become teachers, when they have been appointed as Government Teachers (PNS) have achieved their goals.

2) Being a teacher who is 'perfect', always longs for learning with students in class, otherwise students miss the presence of teachers teaching in class.

3) Work is to meet family needs, so that the peace of the family is too cheap if exchanged for a position that is very short.

4) Many are grateful for God's pleasure in becoming a certified civil servant teacher so that in the work period that is nearing retirement, we must start thinking about not just the affairs of the world alone. 
Refers to the focus of the second problem want to uncover the motives of cause and purpose motives. In this research is able to uncover the motives behind the rational actions taken by the teacher as an actor including: self-experience; policy implementation; understanding religion / beliefs and career systems. The motive for this cause arises based on the reasons raised by the informants in this study.

The results of this study were also able to uncover the motives behind the rational actions taken by teachers as actors including: the realization of ideals; teacher professionalism; peace of family; and a form of gratitude for God's favor.

Based on the above research findings, the description is presented through Figure 2. below:

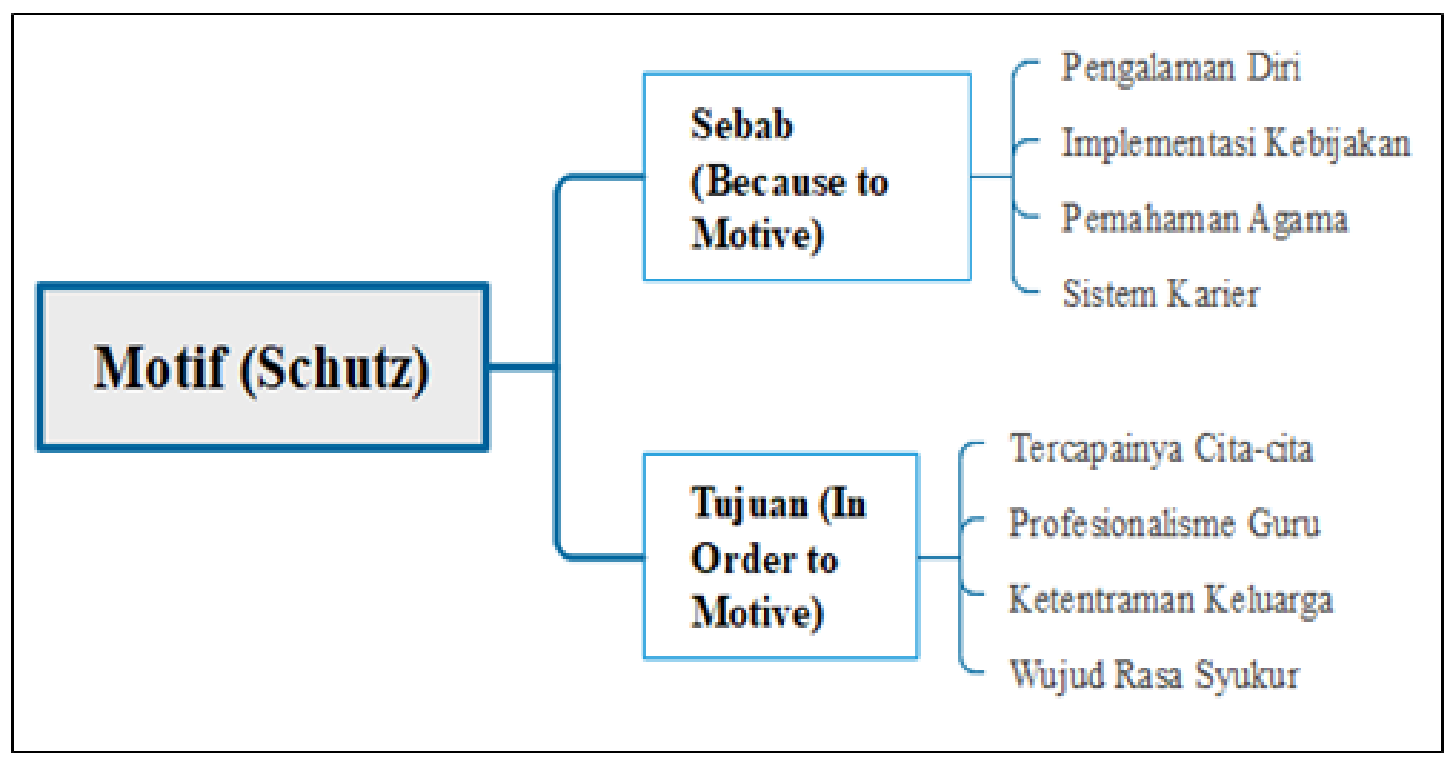

Figure2. Discussion of Research Results with the Phenomenology Theory (Schutz)

Source: Research Results

\section{Proposition}

Based on the conclusions in this study, a proposition can be built as follows:

a. Teacher's Action the negation of career opportunities as a principal is not a spontaneous or subjective action, but through some consideration of the resources owned by the teacher concerned. So that the proposition can be built "theoptimal use of resources owned by the teacher is more profitable for his choice of action"

b. The teacher's action on negating career opportunities as a principal is not an individual act but is a social action so it is related to norms, these norms control the behavior of actions teacher. Then the proposition that can be built is: "behavior in the form of adherence to norms will be beneficial for the actions of the teacher"

c. Motive because the teacher's actions over the negation of career opportunities as a principal. The motives of causes can be distinguished first, the motives for causes that originate from within the teacher include: self-experience and understanding of religion / belief that is adopted. And the second reason motives from outside the teacher themselves are: the implementation of recruitment policies for prospective principals and the teacher's career system. Based on the motives of the cause, the following proposition is built: "the decision on the career negation action as the principal is based on internal causes and external causes, internal causes are more dominant than external causes"

d. The motive for the teacher's action goals on the negation of career opportunities as a principal. The motives for the teacher's actions include: the school the teacher aims to be a teacher; teacher professionalism; work for family peace; and sincerity becomes a form of gratitude for the favor of God. Based on the purpose motives the following proposition is built: "The orientation of the teacher's actions is directed towards the achievement of the goals as a teacher, because the principal's career is not a teacher's orientation so the principal does not make the final goal as a teacher". 


\section{CONCLUSION}

\subsection{Conclusion}

Based on the results of the research presented in Chapter IV of this dissertation report and the discussion and discussion with the theory in Chapter V. It can be concluded that:

a. Teachers as Actors (individuals) have considered resources and norms before making decisions and actions;

b. Connectivity between cases / subjects is in line with the postulate / assumption of rational choice theory;

c. The rationality of actions in the form of negation of the principal's career in the perspective of rational choice theory is unable to reveal the motives for the actor's actions;

d. The motives behind the rational actions taken by the teacher as an actor include: self-experience; policy implementation; understanding religion / beliefs and career systems; dan

e. The motives behind the rational actions taken by the teacher as an actor include: the realization of ideals; teacher professionalism; peace of family; and a form of gratitude for God's favor.

\subsection{Recommendation}

Based on the findings in the field there needs to be improvements related to the recruitment of prospective principals. From some previous studies have a similar view. With sincerity and humility the researchers ventured to provide advice to the Ministry of Education and Culture through the Directorate General of Teachers and Education Personnel (Dirjen GTK) and the Institute for Development and Empowerment of Principals (LPPKS) including: the

1. Head of the Director General of GTK for:

a. Imposing sanctions for violating the implementation of prospective principals' recruitment regarding the recruitment of prospective principals;

b. Making an evaluation of the principal's performance as an evaluation of the principal's position;

c. Evaluation of Government Regulation Number 19 Year 2017 (GoI, 2017) Regarding teacher assignments, an article that specifically discusses not being the duty of principals to teach in class;

d. Making the school committee control functions related to the management of community funds; and

e. Make a teacher career path map.

2. The Head of LPPKS is to carry out education and training independently to teachers who meet the requirements as prospective principals.

\section{REFERENCES}

[1] Baihaqi, Khairuddin, \& Husen, M. (2012). Sistem Rekrutmen, Seleksi dan Penempatan Kepala Sekolah. Jurnal Administrasi Pendidikan Program Pascasarjana Unsyiah, 1(1), 14-28.

[2] Coleman, J. S. (2019). Terjemahan: Foundations Of Social Theory (Dariyanto (ed.); V). Nusa Media.

[3] Creswell, J. W. (2018). Penelitian Kualitatif \& Desain Riset (L. A. L. (ed.); II). Pustaka Pelajar.

[4] Farr, D. T. (2004). School Principal Recrutmen And Selection In Montana [Montana State University]. http://citeseerx.ist.psu.edu/viewdoc/download?doi=10.1.1.919.1024\&rep=rep1\&type=pdf\%0A

[5] Fatah, H. (2015). MINAT GURU MENJADI KEPALA SEKOLAH PENDAHULUAN Pendidikan merupakan bagian terpenting manusia dalam kehidupan berbangsa dan bernegara. Pendidikan yang berkualitas akan menghasilkan manusia yang berkualitas juga. Manusia yang berkualitas akan menentukan m. 1, 303-314.

[6] Irianto, P. (2014). Evaluasi model rekrutmen kepala sekolah di surakarta [UNIVERSITAS MUHAMMADIYAH SURAKARTA]. In Thesis Universitas Muhammadiyah Surakarta. http://eprints.ums.ac.id/39004/1/Naskah Publikasi.pdf

[7] Isjuandi, \& Sutisna, A. (2017). Evaluasi Program Pendidikan dan Pelatihan Calon Kepala Sekolah di Kabupaten Kayong Utara Provinsi Kalimantan Barat (Studi Evaluatif Model CIPPO Pasca Pendidikan dan Pelatihan). JEP: Jurnal Evaluasi Pendidikan, 8(2), 88-101. https://doi.org/doi.org/10.21009/JEP.082.04 
[8] Maryono. (2015). Sistem rekruitmen, seleksi, penempatan dan pembinaan kepala sekolah. Manajer Pendidikan, 9(2), 147-160. https://ejournal.unib.ac.id/index.php/manajerpendidikan/article/download/ 1110/920

[9] Nugroho, N. (2017). Proptotype Seleksi Calon Kepala Sekolah Berbasis Psychological Testing (Study Determinan Factor Kepemimpinan Kepala Sma Di .... ... (Jurnal Inovasi Dan Teknologi Pembelajaran) Kajian ..., 2005, 182-190. http://journal2.um.ac.id/index.php/jinotep/article/view/2123

[10] Rahmadi. (2019). Evaluasi implementasi kebijakan rekrutmen calon kepala sekolah di lingkungan dinas pendidikan kutai kartanegara. 13(1), 4-12.

[11] Ritzer, G. (2004). Sosiologi Ilmu Pengetahuan Berparadigma Ganda (V). PT. Grasindo.

[12] Ritzer, G., \& Goodman, J. D. (2007). Teori Sosiologi Modern (S. T. WB. (ed.); VII). Kencana Prenada Media Group.

[13] Saifudin. (2015). Makna Kepemimpinan Kepala Sekolah Perempuan di Probolinggo. Universitas Muhammadiyah Malang.

[14] Schutz, A. (1973). On Phenomenology and Social Relations (H. R. Wagner (ed.)). The University of Chicago Press.

[15] Smith, J. A. (2009). Terjemahan “Qualitatif Psikology A Practical Guide To Research Method.” Pustaka Pelajar.

[16] Sumarno. (2015). Studi rekruitmen dan pengembangan profesi kepala sekolah sebagai pimpinan satuan pendidikan di kecamatan selupu rejang. Manajemen Pendidikan, 9/4, 505-515. https://media.neliti.com/media/publications/270738-studi-rekruitmen-dan-pengembangan-profes84c2b837.pdf\%0A

[17] Walid, M. (2018). Nilai dan Keyakinan, Kreatifitas, dan Kepemimpinan Kepala Madrasah dalam Mengelola Madrasah Ibtidaiyah Negeri Malang 1 Kota Malang. Al Ibtida: Jurnal Pendidikan Guru MI, 5(1), 107. https://doi.org/10.24235/al.ibtida.snj.v5i1.2729

[18] Wasitohadi. (2014). Evaluasi implementasi kebijakan rekrutmen kepala sekolah sd negeri di kota salatiga (. 1(Paradigma Pendidikan), 1-17.

Citation: Irianto, et.al. "Rationality of Teacher for Principal Career Opportunities Negation" International Journal of Humanities Social Sciences and Education (IJHSSE), vol 7, no. 8, 2020, pp. 39-49. doi: https://doi.org/10.20431/2349-0381.0708005.

Copyright: (C) 2020 Authors. This is an open-access article distributed under the terms of the Creative Commons Attribution License, which permits unrestricted use, distribution, and reproduction in any medium, provided the original author and source are credited. 